Бојан Ђорђевић

Универзитет у Београду

Филолошки факултет

nalesko1965@gmail.com

\title{
ДИГИТАЛНА КАРТОТЕКА ЖИТЕЉА ГРАДА БЕОГРАДА КАО КЊИЖЕВНОИСТОРИЈСКИ ИЗВОР
}

Сажетак: У раду се анализира значај дигитализоване Картотеке житеља града Београда која се чува у Историјском архиву Београда. Дигитализација ове обимне грађе од преко милион пријавних листова (од 1922. до 1954. године) значајна је због заштите те грађе, њене оперативне вредности, а посебно због изузетне важности за науку и културу. Међу пријављеним житељима Београда истичу се имена познатих књижевника, српских и хрватских, који су краће или дуже време боравили, или стално живели, у Београду и Земуну. Указује се на структуру Пријавног листа, те на значај података садржаних у њему за истраживање биографије књижевника.

Кључне речи: Картотека житеља града Београда, дигитализација, архивска грађа, књижевна истрија, документарни извор.

1.

Дигитализација архивске грађе представља данас један од најважнијих архивистичких послова, како на плану заштите саме грађе, тако и у сврху омогућавања лакше доступности подацима које та грађа садржи, што је у складу са начелом јавности и слободног приступа грађи. Дигитализација грађе, која је у Србији још пре само десетак година вршена прилично хаотично и несистематично, ${ }^{1}$ данас добија све више вид плански разрађене и вођене активности, у којој се као основни изазов указује одабир грађе која ће бити дигитализована. Као и у случају публиковања грађе, три су основна критеријума - заштита, оперативна вредност и културноисторијски значај. Овим параметрима водили су се у Историјском архиву Београда када су одлучили да дигитализују грађу и омогуће приступ двема обимним целинама. Најпре је то учињено са Збирком цркве-

1 Видети о томе: Слободанка Цветковић, „Дигитализација у архивима у Србији изазови и замке“, Архив, 2010, 1-2, 79-84. 
них матичних књига, а одскора је доступна у дигитализованој форми и Картотека житеља града Београда као део фонда Управе града Београда. Ова картотека коју је београдска полиција (уосталом, као и остале градске полиције у Краљевини СХС/Југославији) почела да води 1922. године по одлуци Министарског Савета, ${ }^{2}$ а по упутству Министарства унутрашњих дела, садржи податке о житељима Београда и Земуна (од 1931. године, када је Земун изгубио статус града и постао део Београда) све до 1954. године. Грађу чини чак 1.030 .000 пријавних листова који се у Историјском архиву Београда чувају у 851 кутији! Не треба посебно наглашавати да је дигитализацијом омогућена потпуна заштита ове драгоцене грађе, а исто тако потенцирана и њена оперативна вредност, јер потомци људи чије податке садржи ова Картотека сада лако могу доћи до њих. Но, значај ове грађе постаје немерљив са културноисторијског становишта, јер она пружа податке о безмало свим значајним личностима које су не само рођене у Београду и живеле у овом граду, већ и које су краће или дуже време боравиле у њему, с обзиром да су у Картотеку уписивани сви они који су боравили у Београду најмање шест месеци. Стога би се, на основу Картотеке житеља града Београда, могао направити огроман списак научних и културних посленика из целе тадашње Краљевине уметника, професора универзитета, научника, политичара - који су у те три деценије живели и радили у главном граду. На овом списку био би и велики број имена југословенских књижевника.

\section{2.}

Картотека житеља града Београда, доступна сада у дигитализованој форми, представља, дакле, прворазредан књижевноисторијски извор, пре свега када је реч о њиховој биографији, с обзиром на податке који су садржани у Пријави. Структура Пријаве била је следећа:

Улица, број, спрат.

Име породично и рођено.

Занимање.

Држављанство.

Дан, месец и година рођења.

Место рођења, срез, земља.

2 Архив Југославије /даље: АJ/, 138-6-28. 
Завичајна општина, срез, земља.

Брачно стање.

Bepa.

Рођено име оца и мајке, и мајчино девојачко презиме.

Ранији стан у Београду, или у ком другом месту.

Жена и деца испод 18 година - рођено име и девојачко

породично име жене и рођено име деце.

Напомена.

,Власник куће-станодавац.

Датум пријаве.

Ево како је то изгледало на примеру Десанке Максимовић:

Улица, број, спрат: Доситејева 11.

Занимање: професор.

Држављанство: југословенско.

Дан, месец и година рођења: 3. V 1898.

Место рођења, срез, земља: Рабровица, Ваљевски срез.

Завичајна општина, срез, земља: Рабровица, Ваљевски срез.

Брачно стање: неудата.

Вера: православна.

Рођено име оца и мајке, и мајчино девојачко презиме:

Михаило, Драгиња Петровић.

Ранији стан у Београду, или у ком другом месту:

Прилепска 5.

Напомена: венчана 31. VII 1933 за Сластиков Сергија.

Власник куће-станодавац: Максимовић Драгиња.

Датум пријаве: 10. IX 1932.

Пријава Десанке Максимовић показује и како су се ажурирали подаци. Дакле, у тренутку пријаве Управи града Београда, 10. септембра 1932. године, Десанка Максимовић била је неудата. Следеће године у рубрику „Напомена“ уписан је датум венчања и име и презиме супруга. Како Сергеј Сластиков и Десанка Максимовић нису имали деце, то је та рубрика до краја остала празна. Из Пријаве се види да је Десанка Максимовић и сама, а и доцније са мужем, становала са мајком (за време окупације и после Другог светског рата и са сестром и сестрином децом), 
која је у Пријави наведена као власник куће (стана). ${ }^{3}$ Такође, тај стан није био њихов први у Београду. У Доситејеву улицу они су се доселили из Прилепске улице.

3.

Понекад се доводи у сумњу поузданост дигитализованог документа, „јер истраживач поред изучавања садржаја треба да критички оцени спољна обележја историјског извора. “4 Међутим, ако је већ установљена поузданост, оригиналност и аутентичност изворног документа, онда се чињенице које су у њему садржане могу сагледавати, анализирати и валоризовати и на основу дигиталне копије, с тим што то понекад захтева и консултацију других документарних извора на класичној подлози. Са таквог становишта треба пажљиво приступити и подацима које садрже пријаве у Картотеци житеља града Београда.

Што се тиче књижевника, може се утврдити да подаци садржани у Картотеци имају висок степен поузданости и да су у највећој мери тачни, те да се могу упоређивати са подацима добијеним књиженовисторијским изучавањима, а у неким деловима чак могу и допунити та сазнања. На основу пријава четрдесет шест српских и хрватских књижевника, које смо издвојили (од иоле познатијих књижевника једино нема пријаве Станислава Винавера), може се закључити да је велика већина података поуздана. И када би се понекад грешило, то никада не би било у рубрикама о датуму и месту рођења, те именима родитеља. То је веома важно управо за дигитализовани облик Картотеке, јер је управо по овим параметрима омогућено претраживање. Занимања књижевника су такође у највећој мери тачно наведена, али треба приметити да само уз неке писце стоји да су, поред основног занимања, и „књижевници“ -

3 Иако у пријави Десанке Максимовић нису ажурирани подаци после Другог светског рата, из другог архивског извора сазнајемо да су исти чланови домаћинства, мада на другој адреси, били још и 1952. године, када је Савез књижевника Југославије, 16. јануара те године, упутио молбу Повереништву за станове ИОНО Града Београда да се додели одговарајући стан неколицини књижевника. У том списку стоји и: „Десанка Максимовић, са станом у ул. Лоле Рибара бр. 37, у дворишту, станује са старом мајком, сестром удовицом и двоје сестрине деце и болесним мужем. Има само двособан стан. Потребан јој је већи стан с обзиром на болесника и на могућности њеног књижевног рада.“ АJ, 498-F-110.

4 Бориша Радовановић, „О дигиталној копији као историјском извору“, http://www.arhivistika.edu.rs 
уз Мирослава Крлежу, Рада Драинца, Бранимира Ћосића, Николу Шопа (и то само у другој од укупно три пријаве), Драгишу Васића, Бранислава Нушића, Григорија Божовића, Боривоја Јевтића, Тодора Манојловића и Марка Цара. Уз остале стоји само основно занимање, па су Милош Црњански, Десанка Максимовић, Момчило Настасијевић, Божидар Ковачевић и Душан Матић „професори“; Милица Јанковић „учитељица лепих вештина“; Тин Ујевић, Раде Драинац, Станислав Краков и Хамза Хумо „новинари“ (у случају Драинца и Кракова је наглашено и у којим новинама сарађују). Велибор Глигорић је „секретар Министарства Трговине“, Растко Петровић „секретар Министарства Иностраних Послова“, а Иво Андрић најпре записан као „саветник у Министарству Иностраних Послова“, а потом као „шеф отсека и секретар у Министарству Иностраних Послова“.

Занимљив податак допуњује сазнања о афери Милана Богдановића и његовом разводу, те преласку у другу веру. Из његове пријаве види се да је Богдановић не само напустио породицу - жену Милеву, сина Богдана и кћер Ивану, већ да их је натерао да оду из стана у Војводе Миленка 36, где су живели. Наиме, у напомени стоји да је Богдановић „6. II 1937 одјавио породицу“, што значи да су се они одселили из стана! Но, као што је познато, Богдановић је и пре тога, године 1932, имао аферу са младом новинарком и књижевницом Селеном Дукић. У Картотеци житеља града Београда постоји и њена пријава, која може бити значајна по једном детаљу. Наиме, ретки њени савременици који су писали о њеном књижевном делу истицали су да је на њен карактер и њен живот уопште утицала чињеница да је њен отац, коњички официр, погинуо у почетку Првог светског рата, када је она имала само пет година. ${ }^{5}$ Тај њен жал за оцем и осећај усамљености и незаштићености може се уочити чак и у њеним првим песмама, које је као девојчица од осам и по година објавила у окупационим Beogradskim novinama. ${ }^{6}$ Но, занимљиво је да нигде нема помена о ком се то храбром и одликованом официру радило. Из пријаве у картотеци се, међутим, види да је Селенин отац био Убил Дукић, а захваљујући томе подаци о њему се лако могу пронаћи у Војном архиву.?

5 Сима Цуцић, „Селена Дукић: Велики и мали“, Летопис Матице српске, 1937, CCCXLVIII, 1, 110.

6 Видети: Бојан Ђорђевић, „Прве објављене песме Милице Костић и Селене Дукић: прилог проучавању културног живота у окупираној Србији (1915-1918)“, Српске песникиње: зборник радова, Андрићев институт, Андрићград-Вишеград, 2018, 15-19.

7 Видети: Војни архив, Пописник бр. 2 - лични подаци (Дукић Убил). 
Подаци овакве природе о Драгиши Васићу такође су занимљиви. Васић се пријавио 13. марта 1924. године. После рубрике о жени и деци, где су наведене његова друга супруга Наталија, кћер из првог брака Бранислава и кћер из другог брака Татјана, и пошто је уочи Другог светског рата одјављена Бранислава, која се удала и одселила, у напомени је на почетку окупације, 20. јуна 1941. године, забележено да су „Наталија и Татјана пријављене засебно“. То нам говори да су морале бити принудно исељене из стана у Краља Александра 26, управо у време док је Васић боравио у родном крају, одакле ће августа 1941. године отићи у штаб Драже Михаиловића. Као што знамо, то је био само почетак прогона Васићеве породице од стране немачких и квислиншких власти, јер ће уследити хапшење и одвођење у логор на Бањици.

4.

Неки подаци у Картотеци житеља града Београда, пак, нису тако поуздани, и то углавном они који су добијени, према већ поменутом упутству Министарства унутрашњих послова, „усменим изјашњењем грађанина“. Тако су се, пре свега, прикупљали подаци о вероисповести, а исто тако и подаци о брачном стању. Нама, рецимо, данас остаје само да нагађамо зашто је у пријави Мирослава Крлеже од 19. маја 1928. године - очигледно по његовом изјашњењу о брачном стању - записано да је „нежењен“, мада је он већ девет година био у браку са Белом. ${ }^{8}$ Много је јасније, међутим, зашто у пријави Бранислава Нушића од 20. маја 1924. године није записана његова кћи Гита, јер је већ дуго била удата и није била члан Нушићевог домаћинства. Овде, узгред, треба имати на уму да су у пријаве уписивани само чланови домаћинства, тако да у њима нема података о преминулим супружницима или умрлој деци.

Најинтригантнији податак, међутим, налази се у пријави Милоша Црњанског. Он се Управи града Београда пријавио, и у Картотеку житеља био уписан, 15. маја 1924. године. Сви подаци одговарају досад познатим чињеницама из његове биографије, осим што је као место рођења уписан Алибунар! Тиме се поново доводи у питање место рођења Милоша Црњанског. Све што о томе знамо, заправо, садржи се у мемоарским записима Црњанског у Итаки и коментарима, где он вели да се „родио,

8 Крлежа је тада у Београду због припрема за премијеру његове Aгоније у Народном позоришту. Сачувана су два писма Бели. Miroslav Krleža, Bela, dijete drago: pisma /prir. Vlaho Bogišić/, Naklada Ljevak, Zagreb, 2015, 59-62. 
у Чонграду (као и Геца Кон, мој издавач)... ${ }^{\text {9 }}$ Црњански то пише тек 1959. године, и од тада се та тврдња не подвргава сумњи. Остаје, међутим, питање, откуда Геци Кону, када је издавао Сеобе, податак да се Црњански родио у Иланџи (он ју је, по мађарском изговору, звао Иланча). Ако је Геца Кон тај податак донео 1929. године, он га је највероватније могао добити само од Црњанског. Сада, из пријаве Црњанског у Картотеци житеља града Београда, можемо видети да је тај податак и званично заведен у полицији. И полиција га је могла добити једино од самога писца, или од надлежних служби у општини Алибунар, а можда и у самом Панчеву. У оба случаја, дакле, много је вероватније да је место рођења Црњанског Иланџа, а можда баш и Алибунар, како пише у пријави, јер је Тома Црњански и ту имао родбину. ${ }^{10}$ То што је отац Црњанског у то време био на служби у Чонграду не мора да значи да се мати Марија породила тамо. Никога од родбине њих двоје нису имали у Чонграду, и близу је памети да је Марија отишла да се породи у кругу блиских људи. Марија је, по свему судећи, касније отпутовала са бебом у Чонград, а Црњански је, као што је познато, крштен у православној цркви у облишњем Сентошу. Дакле, за то да је Црњански рођен у Чонграду имамо само његову реченицу у коментарима Итаке. За чињеницу да је рођен у очевој постојбини, у Банату, сведочи податак званично заведен у Управи града Београда, било на основу „усменог изјашњења грађанина“, тј. Црњанског, било на основу обавештења из Управе града Панчева. У оба случаја, склони смо да више верујемо службеном документу какав је Картотека житеља града Београда.

Вреди, најзад, скренути пажњу на још једну карактеристику Картотеке житеља града Београда. Наиме, ова је Картотека имала да послужи, опет према упутству Министарства унутрашњих послова, за „брзо проналажење уписаних лица и вођење евиденције о њиховом боравку у Београду.“ У том смислу, полицијске власти показале су велику флексибилност, и особе уписивале онако како су биле познате у јавности. То је случај и са књижевницима. Тако су уписани Иво Андрић (а не Иван), Драгиша Васић (а не Драгомир), Тин Ујевић (а не Аугустин), без обзира на податке у њиховим крштеницама или службеним легитимацијама. Због тога ћемо у Картотеци житеља града Београда узалуд међу осам особа под именом Радојко Јовановић трагати за познатим књижевником. Он је уписан под уметничким именом Раде Драинаи!

9 Према: Miloš Crnjanski, Poezija, Prosveta, Matica srpska, Mladost, Svjetlost, Beograd, Novi Sad, Zagreb, Sarajevo, 1966, 109. У Картотеци житеља града Београда је и пријава Геце Кона, са уписаним Чонградом као местом рођења.

10 Видети: Историјски архив Панчево, Збирка црквених матичних књига. 
5.

На крају, треба поменути још бар једну корист од дигитализоване Картотеке житеља града Београда када су у питању књижевници. На основу ове картотеке може се, у наведеном периоду, прилично поуздано установити својеврсна топографија, тј. локализовати улице и крајеви Београда у којима су писци између два рата живели. Овде треба ставити ограду да сигурно неки од њих, нарочито они који су се чешће селили, нису увек пријављивали све адресе, али и поред тога врло је занимљиво видети где су све наши књижевници становали. Огромна већина, најпре, није имала своје станове, па ако нису становали код родитеља, попут Душана Матића пре женидбе (у Ломиној улици), Десанке Максимовић (у Доситејевој улици), или Бранимира Ћосића (у Балканској улици), станове су изнајмљивали. Неки од њих, као што је познато, врло су често мењали боравишта, али сва нису уписивана у пријаву. Драинчева адреса у тренутку пријаве, 25. октобра 1935. године, била је Жоржа Клемансоа 4, али је много занимљивије то што је, као ранија адреса у Београду, уписана „редакција Правде“, што значи да је Драинац једно време био без смештаја и спавао у просторијама листа за који је радио! Такође, многим адресама које је у Београду, пријављен или непријављен, променио Ујевић, ${ }^{11}$ сада можемо додати и Улицу Луке Вукаловића 9, како стоји у тренутку пријаве. Најзад, у случају двојице наших најзначајнијих књижевника можемо установити и један циклични ток, који их, пред крај живота, и у стварности, али и на симболичком плану, врло знаковито, враћа готово на оне исте адресе на којима су били пријављени између два светска рата. Тако је адреса Иве Андрића у пријави датираној 10. децембра 1924. године Краља Милана 44, а Милоша Црњанског у пријави из исте године Макензијева 36. Последње боравиште Андрићево било је на данашњем Андрићевом венцу, сасвим близу некадашње адресе, а Црњански је последње године провео у истој улици у којој је био пријављен пола века раније, само је та улица сада носила име маршала Толбухина. Тако се и за једног и за другог писца круг на неки начин и у топографском смислу затворио. Тако би се, напокон, на основу података у Картотеци житеља града Београда могла начинити својеврсна књижевна мапа Београда између два светска рата. Сада је то, захваљујући великом и успешном послу дигитализације који је учињен у Историјском архиву Београда, знатно олакшано, као и многа друга истраживања усмерена успостављању што тачније биографије наших писаца.

11 Неке од тих адреса навео је Н. Јешић. Недељко Јешић, Тин Ујевић и Београд, Службени гласник, Београд, 2008. 


\section{Извори}

Архив Југославије

- Министарство унутрашњих послова

- Савез књижевника Југославије

Војни архив

- Пописник: Лични подаци

Историјски архив Београда

- Управа града Београда: Картотека Житеља града Београда

Историјски архив Панчево

- Збирка црквених матичних књига

Krleža, Miroslav (2015). Bela, dijete drago: pisma /prir. Vlaho Bogišić/. Zagreb: Naklada Ljevak.

Crnjanski, Miloš (1966) Poezija. Beograd, Novi Sad, Zagreb, Sarajevo: Prosveta, Matica srpska, Mladost, Svjetlost.

Литература

Ђорђевић, Бојан (2018). „Прве објављене песме Милице Костић и Селене Дукић: прилог проучавању културног живота у окупираној Србији (1915-1918)“. Српске песникиње: зборник радова /ур. Александра Вранеш/. Андрићград-Вишеград: Андрићев институт; стр. 9-20.

Јешић, Недељко (2008). Тин Ујевић и Београд. Београд: Службени гласник.

Радовановић, Бориша (2009). „О дигиталној копији као историјском извору“. http:// www.arhivistika.edu.rs

Цветковић, Слободанка (2010). „Дигитализација у архивима у Србији - изазови и замке“. Архив, 1-2; стр. 79-84.

Цуцић, Сима (1937). „Селена Дукић: Велики и мали“, Летопис Матице српске, CCCXLVIII, 1; стр. 109-111. 


\section{Bojan Đorđević}

University of Belgrade

Faculty of Philology

nalesko1965@gmail.com

\section{DIGITALIZED FILES OF THE INHABITANTS OF THE CITY OF BELGRADE AS A LITERARY-HISTORICAL SOURCE}

Summary: The paper analyzes the significance of the digitized File of the inhabitants of the city of Belgrade, which is kept in the Historical Archive of Belgrade. The digitization of this extensive material of over one million application forms (from 1922 to 1954) is important because of the protection of that material, its operational value, and especially because of its exceptional importance for science and culture. Among the registered residents of Belgrade, are the names of famous writers, Serbian and Croatian, who stayed for a short or long time, or lived permanently, in Belgrade and Zemun, stand out. The structure of the Application Form is pointed out, as well as the importance of the data contained in it for the research of the writer's biography.

Keywords: File of the inhabitants of the city of Belgrade, digitization, archival material, literary history, documentary source. 